\title{
Brand Awareness and Brand Equity of Outpatient
}

\author{
Serlly Frida Drastyana \\ STIKES Yayasan RS Dr. Soetomo Surabaya, Indonesia \\ Jalan Karang Menjangan Nomor 12, Kota Surabaya, Jawa Timur 60286 \\ *Corresponding author: ser_lly@ymail.com
}

\begin{abstract}
Background: The effort to build awareness in the minds of consumers of a particular brand is an important part that needs to create the uniqueness of the brand. Objectives: This study aims to analyse the correlation between Brand Awareness and Brand Equity of outpatient in RSIA Nun Surabaya. Method: This study was analytical observation with cross sectional study. Sample size had 96 outpatient that was taken by simple random. Data analysis used Kendall Tau. Results: The results of this study shown that there are correlation between Brand Awareness and Brand Equity of outpatient in RSIA Nun Surabaya $(p=0,000)$. Conclusion: Brand Awareness correlated with Brand Equity of outpatient in RSIA Nun Surabaya.
\end{abstract}

Keywords : Brand Awareness, Brand Equity, Hospital

\section{INTRODUCTION}

Hospitals are health service institutions that provide full range of personal health services that provide inpatient, outpatient and emergency care services (Depkes RI, 2009). Increasing of hospital counts occurred at General Hospital and Special Hospital and Bed. In 2014, October, data shows that there are currently 2,368 hospitals and predicted the number of hospitals will be 2,809 by 2017 , with a growing rate of hospital counts average 147 per year (Kemenkes RI, 2015). The number of private hospitals is growing rapidly that the growth of these hospitals leads to increasing competition and challenges. Customers increasingly have a selective choice that will affect the existence of an organization. In a hard competitive situation, it is necessary to build the brand (Tjiptono et al, 2008; Vukasovic, 2015).

Brand is a set of consumer associations, which adds perceived value to products and services (Kapferer, 2008; Vukasovic, 2015). Strong brands have an emotional bond with their customers. Emotional ties with consumers will make them have the will to repurchase with the brand in more numbers than competitors of its ilk.

\section{METHOD}

The method of this study was analytical observation with cross sectional study. Research sites in RSIA Nun Surabaya . The research was conducted from June to July 2017. The population of this study was outpatient in Surabaya. The sample of this research is some of outpatient of RSIA Nun Surabaya during the research was 96 people with simple random sampling technique. This study used a questionnaire. Data analysis used Kendall Tau. 


\section{RESULT AND DISCUSSION}

Brand Awareness generated from the questionnaire will be calculated score of each attribute. Based on the results of questionnaires obtained Brand Awareness RSIA Nun Surabaya according to the outpatient customer perceptions with criteria strongly disagree, disagree, agree, and strongly agree.

Table 1 Brand Awareness Distribution RSIA Nun Surabaya According to Outstanding Customer Perception In 2017

\begin{tabular}{|c|c|c|c|c|c|c|c|c|c|c|c|}
\hline \multirow[t]{2}{*}{ No } & \multirow[t]{2}{*}{ attribute } & \multicolumn{2}{|c|}{$\begin{array}{l}\text { strongly } \\
\text { disagree }\end{array}$} & \multicolumn{2}{|c|}{ disagree } & \multicolumn{2}{|c|}{ agree } & \multicolumn{2}{|c|}{$\begin{array}{l}\text { strongly } \\
\text { agree }\end{array}$} & \multicolumn{2}{|c|}{ Total } \\
\hline & & $\mathrm{n}$ & $\%$ & $\mathrm{n}$ & $\%$ & $\mathrm{n}$ & $\%$ & $\mathrm{n}$ & $\%$ & $\mathrm{n}$ & $\%$ \\
\hline 1. & $\begin{array}{l}\text { Hospital in west Surabaya } \\
\text { that came to my mind the } \\
\text { first time was RSIA Nun }\end{array}$ & 0 & 0 & 24 & 25 & 51 & 53,1 & 21 & 21,9 & 96 & 100 \\
\hline 2. & $\begin{array}{l}\text { RSIA Nun can be } \\
\text { remembered well }\end{array}$ & 0 & 0 & 1 & 1 & 63 & 65,6 & 32 & 33,3 & 96 & 100 \\
\hline 3. & $\begin{array}{l}\text { Marketing of RSIA Nun } \\
\text { can attract interest to seek } \\
\text { treatment }\end{array}$ & 0 & 0 & 3 & 3,1 & 66 & 68,8 & 27 & 28,1 & 96 & 100 \\
\hline 4. & $\begin{array}{l}\text { RSIA Nun known for its } \\
\text { quality not because of its } \\
\text { price }\end{array}$ & 0 & 0 & 3 & 3,1 & 53 & 55,2 & 40 & 41,7 & 96 & 100 \\
\hline 5. & $\begin{array}{lll}\text { I treated in RSIA Nun } \\
\text { because it gives } & \text { more } \\
\text { benefits than } & \text { other } \\
\text { hospitals } & & \\
\end{array}$ & 0 & 0 & 0 & 0 & 58 & 60,4 & 38 & 39,6 & 96 & 100 \\
\hline
\end{tabular}

Table 1 shows that most of the respondents strongly agree that RSIA Nun is known for its quality not because of its price (41.7\%), agreed RSIA Nun marketing activities can attract medical treatment $(68,8 \%)$, and disagree West Surabaya Hospital which came to my mind the first time is RSIA Nun (25\%).

Based on the results of questionnaires obtained Brand Awareness RSIA Nun Surabaya according to perception of outpatient customers in 2017 with bad criteria, good, and very good.

Table 2 Result of Brand Awareness RSIA Nun Surabaya According to Customers Outpatient In 2017

\begin{tabular}{lcc}
\hline \multicolumn{1}{c}{ Brand Awareness } & $\mathrm{n}$ & $\%$ \\
\hline Bad & 0 & 0 \\
Good & 39 & 40,6 \\
Very good & 57 & 59,4 \\
Total & 96 & 100 \\
\hline
\end{tabular}

Table 2 shows that Brand Awareness RSIA Nun Surabaya according to perception of outpatient customer in 2017 included in very good category. The relationship between product and product class is the key to making the brand a success. Brands that maintain the highest recall and recognition rate in this class of products will have an extraordinary advantage in the future by utilizing the brand further, in terms of brand extension and advertising campaigns (Aaker, 1995; Pirayesh and Ghaempanah, 2014). Brand awareness also helps consumers in making decisions because it has realized the brand, otherwise if the prospective consumer is not aware of the brand then the consumer will not buy the product. Familiarity and recognition create the basis of trust, and to build a higher trust then the 
company should also maintain its credibility above consumer expectations (Aaker and Joachimthaler, 2000; Jahandoost \& Bahrami, 2013).

Table 3 Result of Brand Equity RSIA Nun Surabaya According to Customers Outpatient In 2017

\begin{tabular}{lcc}
\hline \multicolumn{1}{r}{ Brand Equity } & $\mathrm{n}$ & $\%$ \\
\hline Bad & 0 & 0 \\
Good & 42 & 43,8 \\
Very good & 54 & 56,3 \\
Total & 96 & 100 \\
\hline
\end{tabular}

Table 3 shows that the result Brand Equity of outpatient perception are very good category. The correlation Brand awareness with brand Equity of Outpatient in RSIA Nun Surabaya can be seen in table 4 .

Table 4 Result of the correlation between Brand Awareness and Brand Equity of outpatient in RSIA Nun Surabaya

\begin{tabular}{cc}
\hline Variable & Brand Equity \\
\cline { 2 - 2 } Brand Awareness & 0,000 \\
\hline
\end{tabular}

Table 4 shows that the result of Brand Awareness statistic test with Brand Equity of RSIA Nun Surabaya Outpatient with $\mathrm{p}$ value $=0,000$ which means Brand Awareness correlated with Brand Equity of Outpatient in RSIA Nun Surabaya because p>0,05. A brand of high awareness will help the associations stick to the brand because the brand's roaming power is very high in the minds of consumers. If brand awareness is very high, consumers will be very familiar with the brand, and eventually will arise a sense of love for the brand marketed (Sumarwan et al, 2010). Brand awareness can indicate the existence, commitment, and core that is very important for a company. Brands with high top of mind have high value of consideration (Aaker and Joachimthaler, 2000). Consumers usually do not establish relationships with a particular product or service but instead build a strong relationship with a particular brand (Bilselengin, 2016, Gul \& Bozok, 2015, Khasanah, 2013). Consumers will react differently to products or services that are branded compared to others, so a brand has a positive brand equity if the consumer reacts to the brand more than any other brand (Kotler and Armstrong, 2010, Jahandoost \& Bahrami, 2013, Shanteau \& Hilgenkamp, 2010, Battistoni et al, 2013).

\section{CONCLUSION}

Brand Awareness RSIA Nun Surabaya according to perception of outpatient customer in 2017 included in very good category. Brand Awareness correlated with Brand Equity of outpatient in RSIA Nun Surabaya. Suggestion in this research is improvement of marketing / promotion service so that Nun's mother and child hospital in the first time of customers mind by making leaflet and brochure (Saeednia \& Sohani, 2013, Pirayesh R.,\& Ghaempanah M, 2014).

\section{REFERENCES}

Aaker D.A (1995), Building the Strong Brand, New York: The Free Press.

Aaker D.A \& Joachimthaler E (2000), Brand Leadership, London : The Free Press. 
Battistoni et al (2013), Prominent Determinants of Consumer-Based Brand Equity. International Journal of Engineering Business Management, 5():25 DOI $10.5772 / 56835$

Bilselengin (2016), Brand Equity Within The Framework Of Branding Concept. Öneri, 12(46):277-294 DOI 10.14783/od.v12i46.1000010015

Departemen Kesehatan Republik Indonesia (2009), Undang Undang Republik Indonesia Nomor 44 Tahun 2009 Tentang Rumah Sakit.

Gul \& Bozok (2015), Creating Customer - Based Brand Equity and Measuring Brand Perception of Tourists who Travel for Thermal Tourism: Balcova Survey. Işsletme Araştırmaları Dergisi, 7(3):432-456

Jahandoost \& Bahrami (2013), Investigating the effects of Iranian cultural factors on brand equity for strategic management of market share. Management Science Letters, 3(12), 3047-3058

Kapferer J. N, (2008), The New Strategic Brand Management, $4^{\text {th }}$ ed. London : Kogan Page, Ltd.

Kemenkes RI, (2015), Rencana Strategis Kementerian Kesehatan Tahun 2015-2019. Jakarta : Kementerian Kesehatan RI.

Khasanah I (2013), Analisis Pengaruh Ekuitas Merek Terhadap Keputusan Pembelian Mie Instan Sedaap Di Semarang. Jurnal Dinamika Manajemen, 4(1):93-102

Kotler P.,\& Armstrong G (2010), Principles of Marketing. Global edition. $1^{3 \text { th }}$ ed. New jersey : Pearson Education, Inc.

Pirayesh R.,\& Ghaempanah M (2014), The effects of multimedia advertising on building brand equity. Management Science Letters, 4(7), 1761 - 1764.

Saeednia \& Sohani (2013), An investigation on the effect of advertising corporate social responsibility on building corporate reputation and brand equity. Management Science Letters, 3(4), 1139-1144

Shanteau \& Hilgenkamp (2010), Functional Measurement Analysis of Brand Equity: Does Brand Name affect Perceptions of Quality?. Psicológica, 31(3), 561-575

Sumarwan et al (2010), Analisis Ekuitas Merek Laptop Pada Mahasiswa Institut Pertanian Bogor. Jurnal Ilmu Keluarga dan Konsumen, 3(2), 190-196 DOI 10.24156/jikk.2010.3.2.190

Tjiptono, F., Gregorius C \& Dedi A, (2008), Pemasaran Strategik. Yogyakarta : ANDI

Vukasovic T (2015), Managing Consumer-Based Brand Equity in Higher Education. Managing Global Transitions, 13(1), 75-90 